\title{
Ceria-supported ruthenium catalysts for the synthesis of indole via dehydrogenative $\mathrm{N}$ - heterocyclization
}

\section{$\operatorname{AUTHOR}(S)$ :}

Shimura, Shun; Miura, Hiroki; Wada, Kenji; Hosokawa, Saburo; Yamazoe, Seiji; Inoue, Masashi

\section{CITATION:}

Shimura, Shun ... [et al]. Ceria-supported ruthenium catalysts for the synthesis of indole via dehydrogenative N-heterocyclization. Catalysis Science \& Technology 2011, 1(8): 13401346

\section{ISSUE DATE:}

2011-08

URL:

http://hdl.handle.net/2433/158981

\section{RIGHT:}

(C) Royal Society of Chemistry 2011.; This is not the published version. Please cite only the published version.; この論文は出版社版でありませ ん。引用の際には出版社版をご確認ご利用ください。 


\title{
Ceria-Supported Ruthenium Catalysts for the Synthesis of Indole via Dehydrogenative $N$-Heterocyclization
}

\author{
Shun Shimura, ${ }^{[\mathrm{a}]}$ Hiroki Miura, ${ }^{[\mathrm{a}]}$ Kenji Wada, ${ }^{[\mathrm{a}]} *$ Saburo Hosokawa, ${ }^{[\mathrm{a}]}$ Seiji Yamazoe, ${ }^{[\mathrm{b}]}$ and Masashi \\ Inoue $^{[\mathrm{a}] *}$
}

\author{
5 Received (in $X X X, X X X)$ Xth $X X X X X X X X X 20 X X$, Accepted Xth XXXXXXXXX 20XX \\ DOI: $10.1039 / b 000000 x$
}

Simple heterogeneous $\mathrm{Ru} / \mathrm{CeO}_{2}$ catalysts as well as $\mathrm{Ru} / \mathrm{ZrO}_{2}$ catalysts were found to be quite effective for the selective direct synthesis of indole via intramolecular dehydrogenative $N$-heterocyclization of 2-(2aminophenyl)ethanol, while catalysts supported on $\mathrm{SiO}_{2}, \mathrm{Al}_{2} \mathrm{O}_{3}, \mathrm{TiO}_{2}$, and $\mathrm{MgO}$ were less effective.

${ }_{10} \mathrm{Ru} / \mathrm{CeO}_{2}$ catalysts that were calcined at a relatively low temperature, $200{ }^{\circ} \mathrm{C}$, showed excellent activity and gave indole in a yield over $99 \%$ by the reaction at $140{ }^{\circ} \mathrm{C}$ for $24 \mathrm{~h}$ (Ru catalyst $2.5 \mathrm{~mol} \%$ ).

Spectroscopic studies of the $\mathrm{Ru} / \mathrm{CeO}_{2}$ catalysts indicated the formation of $\mathrm{Ru}^{\mathrm{IV}}=\mathrm{O}$ species on the surface, which is considered to be transformed to the catalytically-active species at the initial stage of the reaction. Hot filtration tests and an ICP-AES analysis indicated that these $\mathrm{Ru} / \mathrm{CeO}_{2}$ catalysts act heterogeneously

15 and that the leaching of ruthenium species into the solution is negligible. These catalysts could be recycled without a significant loss of activity, which suggests that the present oxide-supported catalysts are promising alternatives to conventional homogeneous catalysts.

\section{Introduction}

The establishment of new environmentally-benign processes for 20 synthesizing organic compounds is an important goal in modern chemistry, ${ }^{[1,2]}$ and the use of heterogeneous solid oxide-based catalysts has attracted much attention because of the advantages, such as the ease of preparation (impregnation and calcination) at low cost, high thermal and chemical stabilities, no contamination 25 of the products by metallic species, and excellent recyclability of the catalysts. ${ }^{[2]}$ Recently, we developed heterogeneous $\mathrm{Ru} / \mathrm{CeO}_{2}$ catalysts $^{[3 \mathrm{a}]}$ that are quite effective for transfer-allylation from homoallyl alcohols to aldehydes, ${ }^{[3 \mathrm{~b}]}$ the direct arylation and alkylation of aromatic C-H bonds, ${ }^{[3 c, d]}$ the addition of carboxylic 30 acids to alkynes, ${ }^{[3 \mathrm{e}]}$ and the coupling of alkynes with acrylates. ${ }^{[3 \mathrm{f}]}$ These results suggest that the $\mathrm{Ru} / \mathrm{CeO}_{2}$ catalysts can be good alternatives to homogeneous, low-valent Ru complex catalysts.

On the other hand, benzo-fused $N$-heterocyclic compounds, particularly indoles, are important chemicals for the synthesis of 35 fine chemicals, pharmaceuticals, and agrochemicals. ${ }^{[4,5]}$ Among various methods for the preparation of indoles, ${ }^{[5]}$ the $N$ heterocyclization of 2-(2-aminophenyl)ethanol and its derivatives $^{[6-10]}$ is a promising protocol, since such alcohols are easily derived from 2-nitrotoluene derivatives and 40 formaldehyde. ${ }^{[8 b]}$ While the reactions in the presence of supported copper or nickel catalysts ${ }^{[6]}$ or a large amount of nitric acid $^{[7]}$ require harsh conditions (e.g., over $200{ }^{\circ} \mathrm{C}$ ), the synthesis of indoles promoted by ruthenium phosphine complexes, ${ }^{[8,9]}$ iridium complexes together with bases, ${ }^{[10]}$ or palladium ${ }_{45}$ complexes with allyl acetate ${ }^{[9]}$ have been reported to proceed smoothly under mild conditions. To the best of our knowledge, however, there have been no previous reports of solid ruthenium catalysts that are effective for the synthesis of indole via $\mathrm{N}$ heterocyclization, whereas a few inorganic solid catalysts have 50 been reported to promote the synthesis of nitrogen-containing compounds. $^{[11]}$

Here, we report the development of heterogeneous $\mathrm{Ru} / \mathrm{CeO}_{2}$ catalysts $^{[3,12]}$ that are effective for the selective synthesis of indole from 2-(2-aminophenyl)ethanol in the absence of any additives. ${ }_{55}$ The preparation conditions and ruthenium precursors of the catalysts greatly affected their activities. Remarkably, catalysts prepared using $\mathrm{Ru}(\mathrm{acac})_{3}$ as a $\mathrm{Ru}$ precursor followed by calcination at a relatively low temperature, $200{ }^{\circ} \mathrm{C}$, showed excellent activity. These catalysts were recyclable without a 60 significant loss of activity, and the leaching of Ru species was negligible, which suggests that the present heterogeneous catalytic system is quite advantageous from both environmental and practical perspectives. The structures of suitable surface ruthenium species, which converted to catalytically active low65 valent ruthenium species during the reactions, are discussed based on the spectroscopic characterization of the catalysts.

\section{Experimental Section}

\subsection{Material}

Tris(acetylacetonato)ruthenium(III) (Aldrich), tris(acetyl70 acetonato)iron(III) (Dojin), tris(acetylacetonato)rhodium(III) (Aldrich), tris(acetylacetonato)iridium(III) (Wako), palladium(II) acetate (Nacalai Tesque), aqueous ammonia solution (28\%, Nacalai Tesque), potassium hydroxide (Nacalai Tesque), tetrahydrofuran (dehydrated, stabilizer-free, Wako), 2-(2- 
aminophenyl)ethanol (Aldrich), mesitylene (Nacalai Tesque), naphthalene (Wako), silica (Cabot, Cab-O-Sil), and alumina (Sumitomo Chemical Co., Ltd, AKP-G015; JRC-ALO-8 equivalent) were obtained commercially and used without further 5 purification. Titania (JRC-TIO-4 (P-25)) was obtained from the Catalysis Society of Japan. Ceria was prepared by treating a solution of cerium(III) nitrate hexahydrate $(12.6 \mathrm{~g}, 29 \mathrm{mmol})$ in $400 \mathrm{~cm}^{3}$ of deionized water with $40 \mathrm{~cm}^{3}$ of a potassium hydroxide solution $\left(3.0 \mathrm{~mol} \mathrm{\textrm {dm } ^ { - 3 }}\right)$ or $35 \mathrm{~cm}^{3}$ of a $28 \%$ aqueous 10 ammonia solution with stirring at room temperature for $2 \mathrm{~h}$. The resulting precipitates were collected by centrifugation and then air-dried overnight at $80{ }^{\circ} \mathrm{C}$. The product was heated in a box furnace at a rate of $10{ }^{\circ} \mathrm{C} \mathrm{min}-1$ and maintained at $400{ }^{\circ} \mathrm{C}$ for 30 $\mathrm{min}$ in air to afford ceria in an excellent ceramic yield. The thus15 prepared ceria samples are designated as $\mathrm{CeO}_{2}(\mathrm{KOH})$ or $\mathrm{CeO}_{2}\left(\mathrm{NH}_{3}\right)$, where the precipitant used for the preparation of the support is shown in parentheses. Zirconia was prepared by a similar method from zirconium oxynitrate (Nacalai Tesque) using a $3.0 \mathrm{~mol} \mathrm{dm}$ potassium hydroxide solution, followed by 20 calcination at $500{ }^{\circ} \mathrm{C}$ for $30 \mathrm{~min}$ in air. Magnesia was prepared from magnesium nitrate (Wako) using a $28 \%$ aqueous ammonia solution, and calcined at $400{ }^{\circ} \mathrm{C}$ in air. Ceria-zirconia mixed oxides were prepared by treating a solution of cerium(III) nitrate hexahydrate and zirconium oxynitrate in $100 \mathrm{~cm}^{3}$ of deionized 25 water with $200 \mathrm{~cm}^{3}$ of a $28 \%$ aqueous ammonia solution (five molar equivalents) with stirring for $1 \mathrm{~h}$ at room temperature. The resulting precipitates were collected by centrifugation and then air-dried overnight at room temperature. The product was heated in a box furnace at a rate of $10{ }^{\circ} \mathrm{C} \mathrm{min}^{-1}$ and maintained at $500{ }^{\circ} \mathrm{C}$ 30 for $30 \mathrm{~min}$ in air to afford ceria-zirconia mixed oxide in an excellent ceramic yield.

\subsection{Physical and Analytical Measurements.}

The products of catalytic reactions were analyzed by GC-MS (Shimadzu GC-MS Parvum 2, Zebron ZB-1 capillary column, i.d. $350.25 \mathrm{~mm}$, length $30 \mathrm{~m}$, at 323-523 K) and gas chromatography (Shimadzu GC14APF, Zebron ZB-1 capillary column, i.d. 0.25 $\mathrm{mm}$, length $30 \mathrm{~m}$ at $323-523 \mathrm{~K}$ ). The amount of evolved hydrogen gas was measured by gas chromatography (Shimadzu GC8AlT, Porapak-Q, i.d. 3 mm, length $2 \mathrm{~m}$, at $343 \mathrm{~K}$ ). Nitrogen 40 adsorption/desorption isotherms were obtained with a computercontrolled automatic gas sorption system (Quantachrome NOVA 4200e). Samples were degassed at $300{ }^{\circ} \mathrm{C}$ for $2 \mathrm{~h}$ just before the measurements. A thermogravimetry and differential thermal analysis (TG-DTA) study was performed using a Rigaku 45 TG8120 system. The sample $(c a .5 \mathrm{mg})$ was heated at a rate of $10{ }^{\circ} \mathrm{C} \mathrm{min}{ }^{-1}$ under a stream of air $\left(50 \mathrm{~cm}^{3} \mathrm{~min}^{-1}\right)$. X-ray powder diffraction (XRD) analysis was performed using $\mathrm{Cu} K \alpha$ radiation and a carbon monochromator (XD-D1, Shimadzu). Diffuse reflectance infrared Fourier transform (DRIFT) spectra were 50 recorded using a Nicolet Magna-IR 560 FT-IR spectrometer with a DRIFT optical configuration. Temperature-programmed reduction (TPR) was carried out with a flow-type reactor. Hydrogen (1.9 vol.\% in Ar; atmospheric pressure; $30 \mathrm{~cm}^{3} \mathrm{~min}^{-1}$ ) was passed through a reaction tube containing the catalyst. The 55 tube was heated with an electric furnace at $2{ }^{\circ} \mathrm{C} \min ^{-1}$, and the amount of $\mathrm{H}_{2}$ consumed was monitored with a TC detector on a Shimadzu 8AIT gas chromatograph. Leaching of ruthenium species from the catalysts during the reaction was investigated by an ICP atomic emission spectroscopic analysis using a Shimadzu ${ }_{60}$ ICPS-1000 III analyzer.

$\mathrm{Ru}$ K-edge X-ray absorption fine structure (XAFS) measurements were performed at the BL01B1 beamline of SPring- 8 with the approval of the Japan Synchrotron Radiation Research Institute (JASRI). The storage ring was operated at 8 ${ }_{65} \mathrm{GeV}$ with a ring current of 98-100 mA. A double-mirror system was used to avoid higher harmonics in the X-ray beam. A Si(311) two crystal monochromator was used. Ru K-edge XAFS spectra were measured in transmission mode using $\mathrm{I}_{0}[100 \% \mathrm{Ar}]$ and $\mathrm{I}$ [75\% Ar diluted with $\mathrm{Kr}$ ] ion chambers and in fluorescence mode 70 using an $\mathrm{I}_{0}$ ion chamber $[100 \% \mathrm{Ar}]$ and a Lytle detector $[100 \%$ $\mathrm{Kr}$. X-ray absorption near-edge structure (XANES) and extended $\mathrm{X}$-ray absorption fine structure (EXAFS) data were analyzed using the REX2000 program (ver. 2.5; Rigaku Corp.). For EXAFS analyses, the oscillation was first extracted from XAFS 75 data using a spline-smoothing method. ${ }^{[13]}$ The XANES spectra were normalized using the absorption intensity at the energy which is $c a .50 \mathrm{eV}$ higher than the absorption edge.

\subsection{Preparation of a Ru/support catalyst}

Supported catalysts were prepared by the impregnation method. 80 To a solution of $\mathrm{Ru}(\mathrm{acac})_{3}(79 \mathrm{mg}, 0.198 \mathrm{mmol})$ in $10 \mathrm{~cm}^{3}$ of THF, $1.0 \mathrm{~g}$ of support was added in air at room temperature. After impregnation, the resulting powder was dried at $80^{\circ} \mathrm{C}$ in air for a day and calcined in air at the prescribed temperature for 30 min to afford the $2.0 \mathrm{wt} \% \mathrm{Ru} /$ support catalyst. The thus-prepared 85 catalyst samples are designated as $\mathrm{Ru} /$ support-xx catalyst (suffix represents the calcination temperature).

\subsection{General procedure for the synthesis of indole (2) from 2-} (2-aminophenyl)ethanol (1) by the $\mathrm{Ru} / \mathrm{CeO}_{2}$ catalyst

All of the reactions were performed using hot stirrers equipped 90 with cooling blocks for refluxing the solution. A typical reaction procedure is as follows: 2-(2-aminophenyl)ethanol 1 (1.0 mmol) and mesitylene $\left(2.0 \mathrm{~cm}^{3}\right)$ were placed in a glass Schlenk tube $(20$ $\mathrm{cm}^{3}$ ) under an argon atmosphere together with the $\mathrm{Ru} / \mathrm{CeO}_{2}$ catalyst $(125 \mathrm{mg}, 0.025 \mathrm{mmol}$ as $\mathrm{Ru}$ ). The reaction mixture was 95 stirred at $140{ }^{\circ} \mathrm{C}$ for $18 \mathrm{~h}$, and then rapidly cooled in an ice bath. After the reaction, the solid catalyst was removed by passing through a $0.45 \mu \mathrm{m}$ PTFE filter (Millipore Millex LH). For isolation of the products, the remaining solution was concentrated under reduced pressure, and the products were then separated by 100 column chromatography (silica gel, 4:1 hexane/EtOAc, v/v), identified by GC-MS, and quantified by GC using naphthalene as an internal standard.

\subsection{Hot filtration tests}

A $20 \mathrm{~cm}^{3}$ Schlenk tube was charged with $1(2.0 \mathrm{mmol})$ and the $105 \mathrm{Ru} / \mathrm{CeO}_{2}$ catalyst $(250 \mathrm{mg}, 0.050 \mathrm{mmol}$ as $\mathrm{Ru}$ ) in mesitylene (4.0 $\mathrm{cm}^{3}$ ) together with an internal standard (naphthalene, $c a .30 \mathrm{mg}$ ) under an argon atmosphere. After the reaction was allowed to proceed for $3 \mathrm{~h}$ at $140{ }^{\circ} \mathrm{C}$, the mixture was filtered through a 0.45 $\mu \mathrm{m}$ syringe filter (Millipore Millex LH) into another preheated ${ }_{110}$ Schlenk tube. The filtrate was stirred at $140{ }^{\circ} \mathrm{C}$, and the conversion and yields of the products were followed by GC analysis.

\section{Results and Discussion}




\subsection{Effect of $\mathrm{Ru} / \mathrm{CeO}_{2}$ catalysts on the synthesis of indole via dehydrogenative $N$-heterocyclization}

The effects of metal oxide-supported $\mathrm{Ru}$ catalysts calcined at 400 ${ }^{\circ} \mathrm{C}$ on the synthesis of indole (2) from 2-(2-aminophenyl)ethanol 5 (1) were examined (eq. 1).<smiles>Nc1ccccc1CCO</smiles>

1

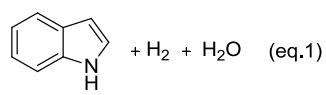

$1.0 \mathrm{mmol}$

The activity of the catalyst was significantly affected by the support (Table1), and, of the ruthenium catalysts examined, the ceria-supported catalyst showed the highest activity. The reaction of $\mathbf{1}$ in mesitylene at $140{ }^{\circ} \mathrm{C}$ for $18 \mathrm{~h}$ in the presence of ${ }_{10} \mathrm{Ru} / \mathrm{CeO}_{2}(\mathrm{KOH})-400$ catalyst selectively gave 2 in a yield of $77 \%$ (entry 3). The formation of a stoichiometric amount of hydrogen gas was confirmed by gas chromatographic analysis, and there was no sign of byproducts, which indicated that the present reaction was completely selective for $\mathbf{2}$. The ruthenium catalyst 15 supported on ceria prepared using aqueous ammonia solution, $\mathrm{Ru} / \mathrm{CeO}_{2}\left(\mathrm{NH}_{3}\right)-400$, showed identical activity under the present conditions (entry 4). The reaction in the absence of the catalyst did not proceed at all, and the ceria support by itself showed a very low catalytic activity (entries 1 and 2). The $\mathrm{Ru} / \mathrm{ZrO}_{2}-400$ 20 catalyst showed a moderate activity (entry 5). On the other hand, catalysts supported on ceria-zirconia mixed oxides showed lower activities than those supported on pure ceria or zirconia (entries 6-8). The ruthenium catalysts supported on $\mathrm{MgO}, \mathrm{TiO}_{2}, \mathrm{Al}_{2} \mathrm{O}_{3}$, and $\mathrm{SiO}_{2}$ were not effective (entries 9-12). The trend in the 25 effects of the supports was similar to that observed in previous reactions promoted by supported Ru catalysts. ${ }^{[3]}$ Among the other transition metal catalysts supported on ceria, Ir and Rh catalysts showed excellent activities comparable to those of the $\mathrm{Ru} / \mathrm{CeO}_{2}$ 400 catalysts (entries 14 and 15), while Fe and Pd catalysts were 30 not very effective (entries 13 and 16). Based on a consideration of the very high costs of producing the Ir and Rh catalysts, we optimized the $\mathrm{Ru} / \mathrm{CeO}_{2}$ catalysts in the following study.

The activities of the ceria-supported catalysts were influenced by ruthenium complexes or salts used as ruthenium precursors for 35 the preparation, as shown in Table 2. Here, $\mathrm{CeO}_{2}\left(\mathrm{NH}_{3}\right)$ was used as a support. Of the catalysts examined, the catalyst prepared using $\mathrm{Ru}(\mathrm{acac})_{3}$ showed the highest activity (Table 2, entry 1 ), while those prepared using $\mathrm{Ru}_{3}(\mathrm{CO})_{12}$ or $\mathrm{RuCl}_{3} \cdot n \mathrm{H}_{2} \mathrm{O}$ showed slightly lower activities (entries 2 and 3 ). On the other hand, the 40 catalysts prepared using $\left[\mathrm{RuCl}_{2}(p \text {-cymene })\right]_{2}$ and $\left[\mathrm{RuCl}_{2}(\mathrm{CO})_{3}\right]_{2}$ showed poor activities (entries 4 and 5). This trend is completely different from those found in the $\mathrm{Ru} / \mathrm{CeO}_{2}$-catalyzed chelationassisted arylation of aromatic $\mathrm{C}-\mathrm{H}$ bonds ${ }^{[3 \mathrm{c}]}$ and the addition of carboxylic acids to alkynes, ${ }^{[3 \mathrm{e}]}$ where $\left[\mathrm{RuCl}_{2}(p \text {-cymene })\right]_{2}$ and

${ }_{45}\left[\mathrm{RuCl}_{2}(\mathrm{CO})_{3}\right]_{2}$ were more suitable. These results suggest that suitable ruthenium precursors depend on the type of the reaction. In the following study, $\mathrm{Ru}(\mathrm{acac})_{3}$ was used as a precursor for the catalysts unless otherwise noted.
Table 1. Effects of the support and metallic species on the activity of the 50 catalysts

\begin{tabular}{|c|c|c|}
\hline Entry & Catalyst $^{a}$ & Yield of $\mathbf{2}(\%)^{b}$ \\
\hline 1 & None & Trace \\
\hline 2 & $\mathrm{CeO}_{2}(\mathrm{KOH})$ & 8 \\
\hline 3 & $\mathrm{Ru} / \mathrm{CeO}_{2}(\mathrm{KOH})-400$ & 77 \\
\hline 4 & $\mathrm{Ru} / \mathrm{CeO}_{2}\left(\mathrm{NH}_{3}\right)-400$ & 77 \\
\hline 5 & $\mathrm{Ru} / \mathrm{ZrO}_{2}(\mathrm{KOH})-400$ & 45 \\
\hline 6 & $\mathrm{Ru} / \mathrm{CeO}_{2}-\mathrm{ZrO}_{2}(80 / 20)-500$ & 39 \\
\hline 7 & $\mathrm{Ru} / \mathrm{CeO}_{2}-\mathrm{ZrO}_{2}(50 / 50)-500$ & 15 \\
\hline 8 & $\mathrm{Ru} / \mathrm{CeO}_{2}-\mathrm{ZrO}_{2}(20 / 80)-500$ & 15 \\
\hline 9 & $\mathrm{Ru} / \mathrm{MgO}\left(\mathrm{NH}_{3}\right)-400$ & 14 \\
\hline 10 & $\mathrm{Ru} / \mathrm{TiO}_{2}-400$ & 6 \\
\hline 11 & $\mathrm{Ru} / \mathrm{Al}_{2} \mathrm{O}_{3}-400$ & 5 \\
\hline 12 & $\mathrm{Ru} / \mathrm{SiO}_{2}-400$ & 5 \\
\hline 13 & $\mathrm{Fe} / \mathrm{CeO}_{2}(\mathrm{KOH})-400$ & 12 \\
\hline 14 & $\mathrm{Rh} / \mathrm{CeO}_{2}(\mathrm{KOH})-400$ & 70 \\
\hline 15 & $\mathrm{Ir} / \mathrm{CeO}_{2}(\mathrm{KOH})-400$ & 76 \\
\hline 16 & $\mathrm{Pd} / \mathrm{CeO}_{2}(\mathrm{KOH})-400$ & 63 \\
\hline
\end{tabular}

55 Table 2. Effects of Ru precursor on the activity of $\mathrm{Ru} / \mathrm{CeO}_{2}\left(\mathrm{NH}_{3}\right)-400^{a}$

\begin{tabular}{ccc} 
Entry & $\mathrm{Ru}$ precursor & Yield of $\mathbf{2}(\%)^{\mathrm{b}}$ \\
\hline 1 & $\mathrm{Ru}(\mathrm{acac})_{3}$ & 77 \\
2 & $\mathrm{Ru}_{3}(\mathrm{CO})_{12}$ & 65 \\
3 & $\mathrm{RuCl}_{3} \cdot n \mathrm{H}_{2} \mathrm{O}$ & 67 \\
4 & {$\left[\mathrm{RuCl}_{2}(p-c y m e n e)\right]_{2}$} & 41 \\
5 & {$\left[\mathrm{RuCl}_{2}(\mathrm{CO})_{3}\right]_{2}$} & 38 \\
\hline
\end{tabular}

${ }^{a}$ Reaction conditions were the same as shown in eq. 1 .

${ }^{b}$ Determined by GLC.

The calcination temperature of the supported $\mathrm{Ru}$ catalysts 60 significantly affected their activities. Table 3 shows the yields of 2 formed by the $\mathrm{Ru} / \mathrm{CeO}_{2}(\mathrm{KOH})$ or $\mathrm{Ru} / \mathrm{Al}_{2} \mathrm{O}_{3}$ catalysts calcined at various temperatures. Note that the use of $\mathrm{Ru}(\mathrm{acac})_{3}$ as a homogeneous catalyst resulted in the formation of $\mathbf{2}$ in a moderate yield (entry 1 ). Both $\mathrm{Ru} / \mathrm{CeO}_{2}(\mathrm{KOH})$ and $\mathrm{Ru} / \mathrm{Al}_{2} \mathrm{O}_{3}$ 65 calcined at below $150{ }^{\circ} \mathrm{C}$ showed catalytic activities similar to that of $\mathrm{Ru}(\mathrm{acac})_{3}$ (entries 1-3,10-11), probably because $\mathrm{Ru}$ species on the surface of these catalysts were not fully oxidized, and basically retained a structure similar to that of $\mathrm{Ru}(\mathrm{acac})_{3}$ (see below). Of the catalysts examined, $\mathrm{Ru} / \mathrm{CeO}_{2}(\mathrm{KOH})-200$ showed 70 the highest catalytic activity (entry 4 ) to afford $\mathbf{2}$ in a yield of $99 \%$ after $24 \mathrm{~h}$. The reaction catalyzed by $\mathrm{Ru} / \mathrm{CeO}_{2}(\mathrm{KOH})-200$ proceeded even in air to give 2 in a yield of $61 \%$ (entry 5). However, a further increase in the calcination temperature of $\mathrm{Ru} / \mathrm{CeO}_{2}$ to above $300{ }^{\circ} \mathrm{C}$ gradually decreased the yield of $\mathbf{2}$ 75 (entries 4, 7-9). On the other hand, the activities of $\mathrm{Ru} / \mathrm{Al}_{2} \mathrm{O}_{3}$ calcined at above $200{ }^{\circ} \mathrm{C}$ were very low (entries 12-15), indicating that ruthenium oxide species on alumina formed by calcination are not active in the present reaction. 
Table 3. Effects of calcination temperature on the activities of $\mathrm{Ru} / \mathrm{CeO}_{2}(\mathrm{KOH})$ and $\mathrm{Ru} / \mathrm{Al}_{2} \mathrm{O}_{3}$ catalysts $^{a}$

\begin{tabular}{ccc}
\hline Entry & $\mathrm{Ru}$ catalyst $^{b}$ & ${\text { Yield of } 2(\%)^{\mathrm{c}}}^{\mathrm{c}}$ \\
\hline 1 & $\mathrm{Ru}(\mathrm{acac})_{3}$ & 42 \\
2 & $\mathrm{Ru} / \mathrm{CeO}_{2}(\mathrm{KOH})-\mathrm{as}-\mathrm{imp}$. & 53 \\
3 & $\mathrm{Ru} / \mathrm{CeO}_{2}(\mathrm{KOH})-150$ & 50 \\
4 & $\mathrm{Ru} / \mathrm{CeO}_{2}(\mathrm{KOH})-200$ & $84(>99)^{d}$ \\
$5^{e}$ & $\mathrm{Ru} / \mathrm{CeO}_{2}(\mathrm{KOH})-200$ & 61 \\
6 & $\mathrm{Ru} / \mathrm{CeO}_{2}(\mathrm{NH})-200$ & 84 \\
7 & $\mathrm{Ru} / \mathrm{CeO}_{2}(\mathrm{KOH})-300$ & 84 \\
8 & $\mathrm{Ru} / \mathrm{CeO}_{2}(\mathrm{KOH})-400$ & 77 \\
9 & $\mathrm{Ru} / \mathrm{CeO}_{2}(\mathrm{KOH})-600$ & 57 \\
10 & $\mathrm{Ru} / \mathrm{Al}_{2} \mathrm{O}_{3}-\mathrm{as}-19 \mathrm{imp}$. & 40 \\
11 & $\mathrm{Ru} / \mathrm{Al}_{2} \mathrm{O}_{3}-150$ & 43 \\
12 & $\mathrm{Ru} / \mathrm{Al}_{2} \mathrm{O}_{3}-200$ & 14 \\
13 & $\mathrm{Ru} / \mathrm{Al}_{2} \mathrm{O}_{3}-300$ & 7 \\
14 & $\mathrm{Ru} / \mathrm{Al}_{2} \mathrm{O}_{3}-400$ & 5 \\
15 & $\mathrm{Ru} / \mathrm{Al}_{2} \mathrm{O}_{3}-600$ & 2
\end{tabular}

${ }^{a}$ Reaction conditions were the same as shown in eq. 1.

${ }^{b} 2.0 \mathrm{wt} \%$ as $\mathrm{Ru} . \mathrm{Ru}(\mathrm{acac})_{3}$ was used as a precursor.

$5^{c}$ Determined by GLC. ${ }^{d}$ Reaction for $24 \mathrm{~h} .{ }^{e}$ Reaction in air.

It is important to investigate whether the reaction actually proceeds on the surface of the solid catalyst. ${ }^{[14,15]}$ To examine the contribution of ruthenium species in solution generated by the so10 called "release and capture" mechanism, the effect of removal of the catalysts by hot filtration through a PTFE filter (pore size 0.45 $\mu \mathrm{m})$ was examined. Figure 1 shows the time-course of the reaction at $140{ }^{\circ} \mathrm{C}$ in the presence of $\mathrm{Ru}(2.0 \mathrm{wt} \%) / \mathrm{CeO}_{2}(\mathrm{KOH})$ 200 catalyst. The formation of $\mathbf{2}$ was completely stopped by 15 removal of the solid catalyst. According to the ICP-AES analysis, very little of the ruthenium species was found in the solution, $0.000075 \mathrm{mmol}$ ( $\mathrm{ca} .0 .15 \mathrm{~mol} \%$ of the ruthenium species charged as the fresh catalyst) after the reaction at $140{ }^{\circ} \mathrm{C}$ for $18 \mathrm{~h}$ catalyzed by $\mathrm{Ru} / \mathrm{CeO}_{2}(\mathrm{KOH})-200$. These results clearly indicate 20 that the reaction proceeds on the surface of the catalysts without significant leaching of ruthenium species into the solution. Therefore, the present heterogeneous $\mathrm{Ru} / \mathrm{CeO}_{2}$ catalyst is markedly superior to conventional homogeneous catalysts.

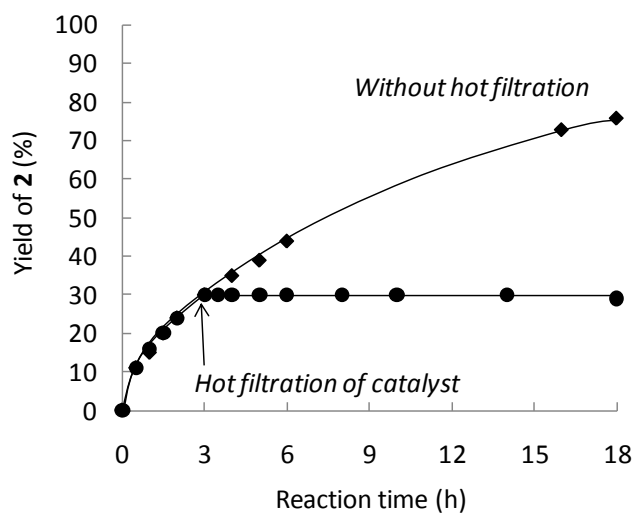

Figure 1. Time-course of the reaction of $\mathbf{1}$ over $\mathrm{Ru} / \mathrm{CeO}_{2}(\mathrm{KOH})-200$. ( $)$ without filtration of the catalyst and $(\bullet)$ with removal of the catalyst by hot filtration after $3 \mathrm{~h}$. Reaction conditions; 1 (2.0 mmol),

$\mathrm{Ru} / \mathrm{CeO}_{2}(\mathrm{KOH})-200(0.050 \mathrm{mmol}$ as Ru$)$, mesitylene $\left(4.0 \mathrm{~cm}^{3}\right)$, at $140{ }^{\circ} \mathrm{C}$.

One of the major advantages of solid catalysts is their recyclability. After the reaction was performed at $140{ }^{\circ} \mathrm{C}$ for $18 \mathrm{~h}$ using $\mathrm{Ru} / \mathrm{CeO}_{2}\left(\mathrm{NH}_{3}\right)-200$ catalyst (Table 3, entry 6), the solid catalyst was separated from the reaction mixture by 35 centrifugation and washed three times with diethyl ether $\left(10 \mathrm{~cm}^{3}\right)$. The resulting solid was calcined at $200{ }^{\circ} \mathrm{C}$ for $4 \mathrm{~h}$. The thusrecycled $\mathrm{Ru} / \mathrm{CeO}_{2}\left(\mathrm{NH}_{3}\right)-200$ catalyst afforded 2 in the same yield (84\%). Similarly, recycled $\mathrm{Ru} / \mathrm{CeO}_{2}(\mathrm{KOH})-200$ gave 2 in a yield of $80 \%$, while the fresh catalyst afforded 2 in $84 \%$ yield. These 40 results clearly indicate that the $\mathrm{Ru} / \mathrm{CeO}_{2}$ catalysts are recyclable.

\subsection{Characterization of supported ruthenium catalysts}

To investigate the factors that govern the activity of the catalysts, a series of supported ruthenium catalysts were characterized. The results of a nitrogen gas adsorption study of the fresh catalysts as 45 well as their XRD patterns are summarized in the Supplementary Information.

The electronic structure and the geometry of the surroundings of ruthenium ions on supports were investigated by means of the XAFS spectra. The EXAFS oscillations and the Fourier ${ }_{50}$ transforms (FT) of the EXAFS spectra are shown in Figure 2. Spectra of $\mathrm{RuO}_{2}$ and $\mathrm{Ru} / \mathrm{Al}_{2} \mathrm{O}_{3}{ }^{[3 f]}$ are also shown for comparison. While the formation of $\mathrm{RuO}_{2}$-like species on $\mathrm{Al}_{2} \mathrm{O}_{3}, \mathrm{SiO}_{2}$ or $\mathrm{TiO}_{2}$ have been suggested, ${ }^{[3 f]}$ the EXAFS spectra of $\mathrm{Ru} / \mathrm{CeO}_{2}(\mathrm{KOH})$ and $\mathrm{Ru} / \mathrm{CeO}_{2}\left(\mathrm{NH}_{3}\right)$ were different from that of $\mathrm{RuO}_{2}$ in the 55 second shell around 3.0 $\mathrm{A}$. In the spectra of these catalysts, the FT peak intensities in the second shell were lower than those of other catalysts. Therefore, ruthenium species which have strong interaction with supports are considered to be formed on $\mathrm{CeO}_{2}{ }^{[16]}$
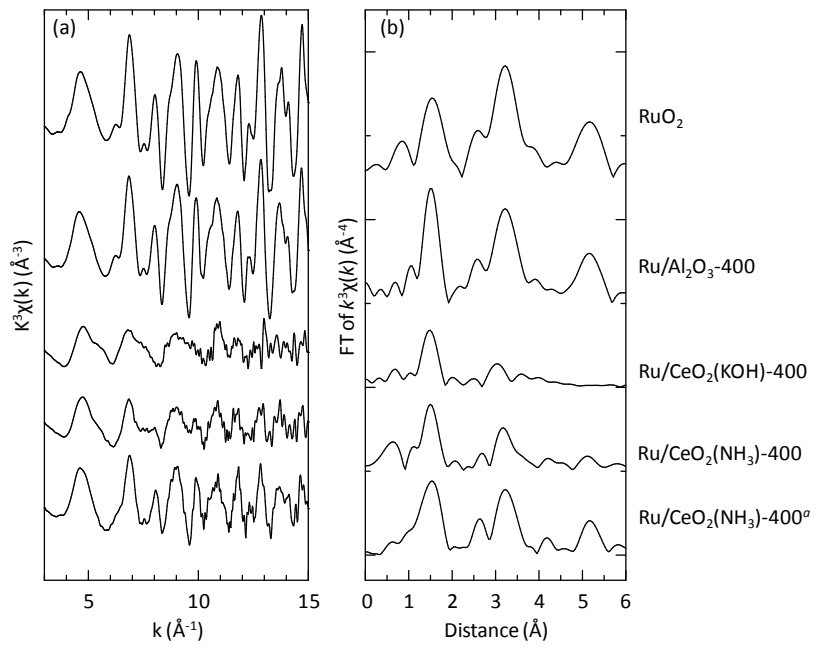

Figure 2. (a) Ru K-edge EXAFS oscillations of $2.0 \mathrm{wt} \% \mathrm{Ru} / \mathrm{support}$ 60 catalysts. $\mathrm{Ru}(\mathrm{acac})_{3}$ was used as a precursor. (b) Ru K-edge FT spectra of the supported-Ru catalysts. ${ }^{a} \mathrm{Ru}_{3}(\mathrm{CO})_{12}$ was used as a precursor.

Figure 3 shows the $\mathrm{Ru} \mathrm{K}$-edge XANES spectra of $\mathrm{CeO}_{2^{-}}$or ${ }_{65} \mathrm{ZrO}_{2}$-supported $\mathrm{Ru}$ catalysts calcined at $400{ }^{\circ} \mathrm{C}$, which were recorded in air at room temperature. As discuss previously, ${ }^{[3 f, 17]}$ a characteristic pre-edge peak was observed at around $22110 \mathrm{eV}$ only in the spectra of $\mathrm{Ru} / \mathrm{CeO}_{2}(\mathrm{KOH})-400, \mathrm{Ru} / \mathrm{CeO}_{2}\left(\mathrm{NH}_{3}\right)-400$, and $\mathrm{Ru} / \mathrm{ZrO}_{2}-400$. This pre-edge peak is assignable to the 70 forbidden transition from the $1 \mathrm{~s}$ to $4 \mathrm{~d}$ level of metal ions. However, distortions that break centrosymmetry can permit $5 \mathrm{p}$ mixing into the empty $4 \mathrm{~d}$ orbital, providing for an electric dipole allowed character in the metal $4 \mathrm{~d} \leftarrow 1 \mathrm{~s}$ transitions. ${ }^{[17,18]}$ For the 
standard $\mathrm{RuO}_{2}$, which has a symmetrical six-coordinated structure as well as $\mathrm{Ru} / \mathrm{Al}_{2} \mathrm{O}_{3}{ }^{[19]}$ the pre-edge peak was very weak. Therefore, the presence of the pre-edge peak in the spectra of $\mathrm{Ru} / \mathrm{CeO}_{2}$ and $\mathrm{Ru} / \mathrm{ZrO}_{2}$ indicates that the $\mathrm{Ru}$ species on ceria 5 and zirconia have a structure that is more distorted than that of $\mathrm{RuO}_{2}$.

10

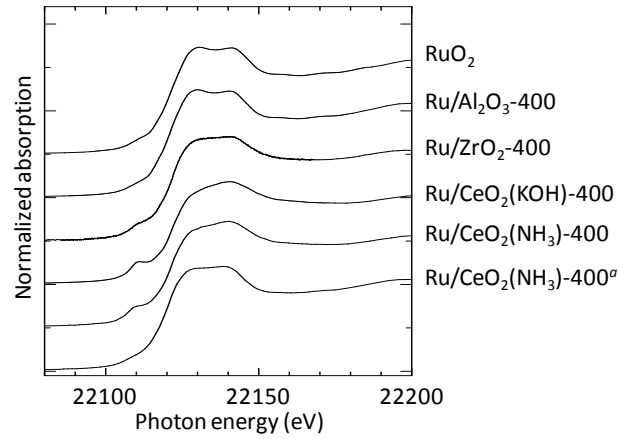

Figure 3. Ru K-edge XANES spectra of $2.0 \mathrm{wt} \% \mathrm{Ru} /$ support catalysts. ${ }_{20} \mathrm{Ru}(\mathrm{acac})_{3}$ was used as a precursor. ${ }^{a} \mathrm{Ru}_{3}(\mathrm{CO})_{12}$ was used as a precursor.

Figure 4 shows the DRIFT spectra of the supported Ru catalysts. Note that both $\mathrm{Ru} / \mathrm{CeO}_{2}(\mathrm{KOH})-400$ and ${ }_{25} \mathrm{Ru} / \mathrm{CeO}_{2}\left(\mathrm{NH}_{3}\right)-400$ using $\mathrm{Ru}(\mathrm{acac})_{3}$ as well as the $\mathrm{CeO}_{2}$ supported catalyst prepared using $\mathrm{Ru}_{3}(\mathrm{CO})_{12}$ showed a characteristic band at around $980 \mathrm{~cm}^{-1}$, which has been assigned to $\mathrm{Ru}=\mathrm{O}$ vibration. ${ }^{[17]}$ On the other hand, the other catalysts did not show distinct bands in this region. Although such a peak was 30 not recognized for $\mathrm{Ru} / \mathrm{ZrO}_{2}$ in the present study, the formation of similar $\mathrm{Ru}=\mathrm{O}$ species has been proposed for zirconia-supported catalysts. ${ }^{[20,21]}$ These results suggest that the formation of $\mathrm{Ru}=\mathrm{O}$ species in freshly calcined catalysts strongly correlates with the catalytic activity. We deduce that the formation of surface $\mathrm{Ru}=\mathrm{O}$ 35 bonds is basically associated with distortion of the coordination around the ruthenium atoms.
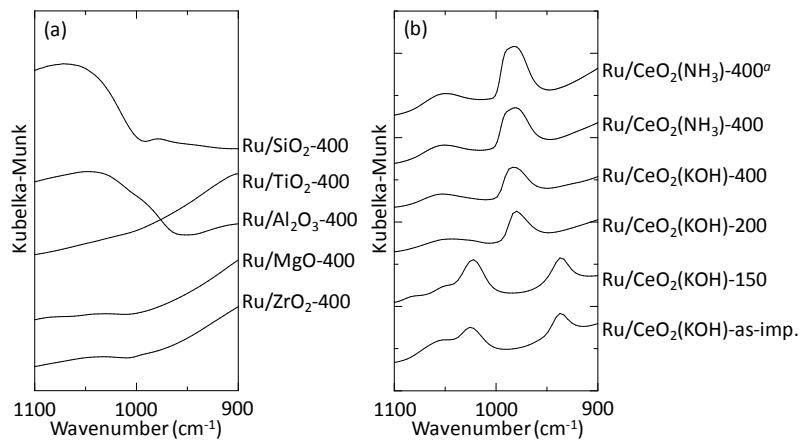

Figure 4. (a) DRIFT spectra of $2.0 \mathrm{wt} \% \mathrm{Ru} /$ support catalysts. Ru(acac) ${ }_{3}$ was used as a precursor. (b) DRIFT spectra of $\mathrm{Ru} / \mathrm{CeO}_{2}$ calcined at various temperatures. ${ }^{a} \mathrm{Ru}_{3}(\mathrm{CO})_{12}$ was used as a precursor.

40

Note that the XANES spectrum of $\mathrm{Ru} / \mathrm{CeO}_{2}\left(\mathrm{NH}_{3}\right)-400$ prepared using $\mathrm{Ru}_{3}(\mathrm{CO})_{12}$ did not show a distinct pre-edge peak, and there was a relatively strong FT peak at around $3.0 \AA$ in its EXAFS spectrum. On the other hand, its DRIFT spectrum ${ }_{45}$ suggests the presence of $\mathrm{Ru}=\mathrm{O}$ species. These results indicate the formation of both $\mathrm{Ru}=\mathrm{O}$ species and $\mathrm{RuO}_{2}$-like species probably because of the trinuclear nature of $\mathrm{Ru}_{3}(\mathrm{CO})_{12}$ precursor, which could explain why it has slightly lower catalytic activity than the catalysts prepared using $\mathrm{Ru}(\mathrm{acac})_{3}$ (see Table 2).

50 The effects of the calcination temperature on the properties of $\mathrm{Ru} / \mathrm{CeO}_{2}(\mathrm{KOH})$ were investigated. There were no significant changes in the BET surface area with a change in the calcination temperature. The TG-DTA profile of as-impregnated $\mathrm{Ru} / \mathrm{CeO}_{2}(\mathrm{KOH})$ shows an exothermic weight decrease at around $55200{ }^{\circ} \mathrm{C}$. The extent of the weight decrease is consistent with the estimation based on the oxidative degradation of acetylacetonato ligands $(5.6 \%)$. The DRIFT spectra of catalysts calcined at various temperatures clearly indicate the changes in the surface species (Figure 4(b)). ${ }^{[3 f]}$ The spectra of as-impregnated ${ }_{60} \mathrm{Ru} / \mathrm{CeO}_{2}(\mathrm{KOH})$ and $\mathrm{Ru} / \mathrm{CeO}_{2}(\mathrm{KOH})-150$ are represented as the superposition of the spectra of $\mathrm{Ru}(\mathrm{acac})_{3}$ and $\mathrm{CeO}_{2}(\mathrm{KOH})$, indicating that $\mathrm{Ru}(\mathrm{acac})_{3}$ or $\mathrm{Ru}(\mathrm{acac})_{3}$-like species remain intact after impregnation and heat treatment at $<150{ }^{\circ} \mathrm{C}$. On the other hand, calcination at $>200{ }^{\circ} \mathrm{C}$ significantly changed the spectra:

65 peaks due to $\mathrm{Ru}(\mathrm{acac})_{3}$ completely disappeared, and a new band appeared at $980 \mathrm{~cm}^{-1}$, clearly indicating the formation of $\mathrm{Ru}=\mathrm{O}$ species by the combustion of surface ruthenium acetylacetonato complexes at $>200{ }^{\circ} \mathrm{C}$.

Our previous study using $\mathrm{Ru} / \mathrm{CeO}_{2}$ catalysts revealed surface ${ }_{70} \mathrm{Ru}^{\mathrm{IV}}=\mathrm{O}$ species are easily reduced to low-valent $\mathrm{Ru}$ species, which show excellent activities in various organic transformations. ${ }^{[3]}$ Therefore, the changes in these $\mathrm{Ru}=\mathrm{O}$ species caused by the catalytic run and by re-calcination for regeneration were monitored by DRIFT spectra. As shown in Figure 5, a 75 characteristic band at $980 \mathrm{~cm}^{-1}$ of the fresh $\mathrm{Ru} / \mathrm{CeO}_{2}(\mathrm{KOH})-200$ catalyst disappeared after the catalytic run. This indicates that $\mathrm{Ru}=\mathrm{O}$ is not a catalytically active species but rather a precursor for catalytically active species formed during the reaction. The band appeared again after re-calcination of the used catalyst, 80 indicating the regeneration of the $\mathrm{Ru}=\mathrm{O}$ species on the surface of the catalyst.

85

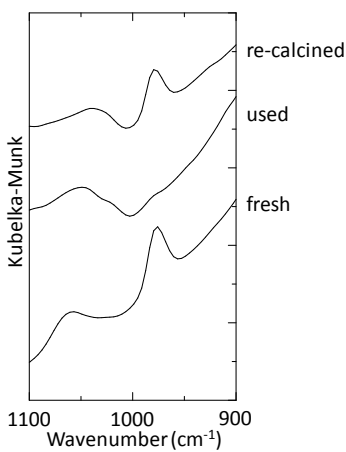

Figure 5. DRIFT spectra of fresh, used, and re-calcined $\mathrm{Ru} / \mathrm{CeO}_{2}(\mathrm{KOH})-$ 95200 .

For the present dehydrogenative $N$-heterocyclization to indole, a pathway via indoline would be possible. The dehydrogenation of indoline in the presence of the $\mathrm{Ru} / \mathrm{CeO}_{2}(\mathrm{KOH})-200$ catalyst $100(2.5 \mathrm{~mol} \%$ as $\mathrm{Ru})$ at $140{ }^{\circ} \mathrm{C}$ for $3 \mathrm{~h}$ gave 2 in a yield of $61 \%$. On the other hand, the reaction of $\mathbf{1}$ under the identical conditions afforded $\mathbf{2}$ in a yield of $30 \%$, but indoline was not detected at all. This result clearly excludes the possibility that indoline participates in the main catalytic cycle, since consecutive first105 order reactions predict the significant formation of indoline ( $\mathrm{ca}$. 
$16 \%$ yield) together with 2 in $30 \%$ yield. A possible mechanism is shown in Scheme 1. It is quite likely that the first step of the reaction is the hydrogen transfer from an alcohol to the $\mathrm{Ru}$ catalyst to form an aldehyde and a hydrido ruthenium species. ${ }_{5}$ The intramolecular nucleophilic attack of amino group to the aldehyde moiety affords a Schiff base, which isomerizes to $\mathbf{2}$ very rapidly. Release of molecular hydrogen from the hydrido ruthenium species regenerates the catalytically active ruthenium species. Similar mechanisms have been proposed for the 10 reactions promoted by homogeneous ruthenium ${ }^{[8 \mathrm{~b}]}$ and iridium ${ }^{[10]}$ complex catalysts.

Scheme 1. A possible reaction mechanim.
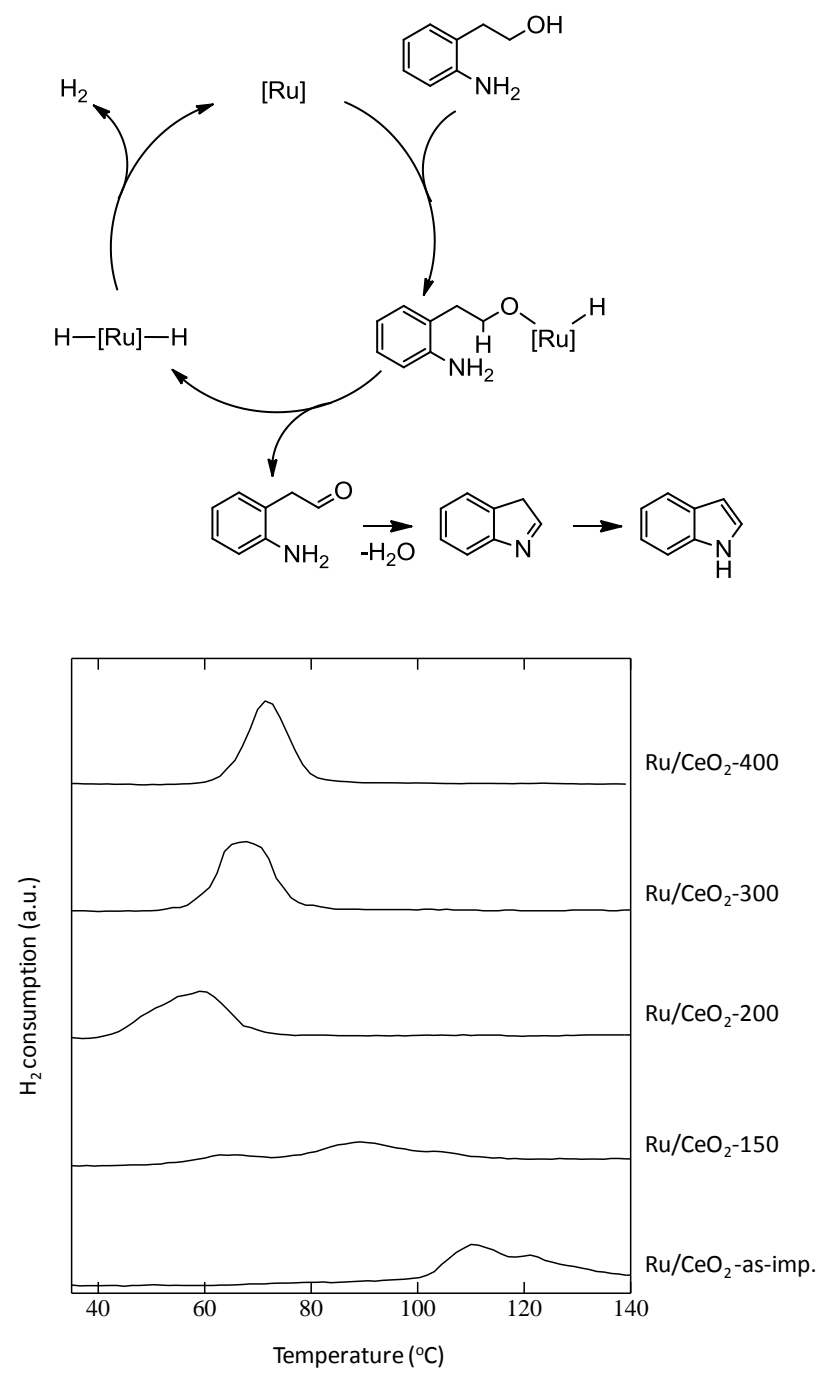

15 Figure 6. $\mathrm{H}_{2}$-TPR profiles of $\mathrm{Ru} / \mathrm{CeO}_{2}$ catalysts calcined at various temperatures.

In the view of the possible mechanism discussed above, the redox ability of the surface ruthenium species might be an important factor that governs the catalytic activity. The 20 temperature required for the reduction of $\mathrm{Ru}=\mathrm{O}$ species also depends on the calcination temperature of the catalysts. As shown in Figure 6, the reduction peak of $\mathrm{Ru} / \mathrm{CeO}_{2}(\mathrm{KOH})$ gradually shifted toward a lower temperature with a decrease in the calcination temperature from $400{ }^{\circ} \mathrm{C}$ to $200{ }^{\circ} \mathrm{C}$. This trend is
25 consistent with that of the catalytic activity shown in Table 3; the catalyst bearing more easily reducible $\mathrm{Ru}=\mathrm{O}$ species shows higher catalytic activity.

In the present reaction as well as the previously-reported $\mathrm{Ru} / \mathrm{CeO}_{2}$-catalyzed reactions, ${ }^{[3]} \mathrm{Ru}^{\mathrm{IV}}=\mathrm{O}$ species having distorted 30 coordination environment would be exclusively formed on ceria or zirconia surface, and this would be a key precursor of the catalytically-active species. However, required properties for surface $\mathrm{Ru}^{\mathrm{IV}}=\mathrm{O}$ species significantly depend on the types of the reactions. For example, the coupling of alkynes with acrylates 35 proceeded much smoothly over the catalyst calcined at higher temperature, namely $600{ }^{\circ} \mathrm{C}::^{[3 f]}$ The catalytic activities positively correlated the degree of the distortion of $\mathrm{Ru}^{\mathrm{IV}}=\mathrm{O}$ species. Furthermore, not only the surface active species but also a very small amount of soluble ruthenium species was found to be 40 responsible for the coupling reactions. ${ }^{[3 f]}$ On the other hand, $\mathrm{Ru} / \mathrm{CeO}_{2}$ calcined at low temperature, $200{ }^{\circ} \mathrm{C}$, showed the highest activity for the present dehydrogenative $N$-heterocyclization. As shown in $\mathrm{H}_{2}$-TPR profiles, the catalyst having $\mathrm{Ru}^{\mathrm{IV}}=\mathrm{O}$ species reducible at lower temperature showed higher activity. In 45 addition, the hot filtration test clearly indicated that the reaction proceeded on the solid catalyst. Obviously, the nature of the active species generated in situ from $\mathrm{Ru}^{\mathrm{IV}}=\mathrm{O}$ species was quite different in both reactions. These results suggest that the strict control of the properties of $\mathrm{Ru}^{\mathrm{IV}}=\mathrm{O}$ species is very important to 50 generate suitable active ruthenium species.

\section{Conclusions}

For the synthesis of indole via the dehydrogenative cyclization of amino alcohol, $\mathrm{Ru} / \mathrm{CeO}_{2}$ as well as $\mathrm{Ru} / \mathrm{ZrO}_{2}$ acts as effective 55 heterogeneous catalysts. The activity crucially depends on the nature of the support, and catalysts supported on $\mathrm{SiO}_{2}, \mathrm{Al}_{2} \mathrm{O}_{3}$, $\mathrm{TiO}_{2}$, and $\mathrm{MgO}$ are less effective. The calcination temperature of the catalysts influences the activity, and the $\mathrm{Ru} / \mathrm{CeO}_{2}$ catalyst calcined at $200{ }^{\circ} \mathrm{C}$ shows the highest activity, to afford indole in a 60 yield over $99 \%$ by the reaction at $140{ }^{\circ} \mathrm{C}$ for $24 \mathrm{~h} . \mathrm{Ru}^{\mathrm{IV}}=\mathrm{O}$ species interacted with supports are considered to be formed on ceria and zirconia, which act as good precursors for the catalytically active reduced surface ruthenium species.

The present $\mathrm{Ru} / \mathrm{CeO}_{2}$ catalyst is recyclable, and the leaching of 65 ruthenium species is negligible. According to the hot filtration test, $\mathrm{Ru} / \mathrm{CeO}_{2}$ acts as a truly heterogeneous catalyst. Furthermore, note that the present system does not require any additives. Due to these characteristic features, $\mathrm{Ru} / \mathrm{CeO}_{2}$ is quite attractive as an environmentally benign, highly efficient heterogeneous catalyst 70 from synthetic, industrial, and environmental perspectives. Furthermore, extensive and systematic investigation on the intraand intermolecular reactions between various amines and alcohols by the present catalysts as well as other precious metal catalysts supported on ceria is in progress.

\section{${ }_{75}$ Acknowledgements}

This research was supported by a Grant-in-Aid for Scientific Research (No. 21360393) from the Ministry of Education, Culture, Sports, Science and Technology, Japan. This work has been performed with the approval of SPring- 8 (Proposal No. 
2009B1356). K. W. acknowledges financial support from the Takahashi Industrial and Economic Foundation.

\section{Notes and references}

a Department of Energy and Hydrocarbon Chemistry, Graduate School 5 of Engineering, Kyoto University, Katsura, Nishikyo-ku, Kyoto 615-8510 (Japan). Fax: +81-75-383-2479 Tel: +81-75-383-2482; E-mail: wadaken@scl.kyoto-u.ac.jp

${ }^{\mathrm{b}}$ Department of Materials Chemistry, Graduate School of Science and Technology Ryukoku University, Seta, Otsu 520-2194 (Japan)

10 †Electronic Supplementary Information (ESI) available: See DOI: $10.1039 / \mathrm{b} 000000 \mathrm{x} /$

1. For green chemistry, see: a) P. T. Anastas, J. Warner, Green Chemistry: Theory and Practice; Oxford University Press: New York 1998. (b) R. A. Sheldon, R. S. Downing, Appl. Catal. A: General

15 1999, 189, 163-183. (c) B. M. Trost, Acc. Chem. Res. 2002, 35, 695 705.

2 For representative reviews, see: (a) P. Laszlo, Acc. Chem. Res. 1986, 19, 121-127. (b) Y. Izumi, M. Onaka, Adv. Catal. 1992, 38, 245-282. (c) J. H. Clark, D. J. Macquarrie, Chem. Soc. Rev. 1996, 25, 303-310.

20 (d) B. F. Sels, D. E. De Vos, P. A. Jacobs, Catal. Rev. Sci. Eng. 2001, 43, 443-488. (e) S. Kannan, Catal. Surv. Asia 2006, 10, 117-137. (f) K. Kaneda, Synlett 2007, 999-1015.

3 (a) K. Wada, S. Hosokawa, M. Inoue, Catal. Surv. Asia 2010, 15, 1-11. (b) H. Miura, K. Wada, S. Hosokawa, M. Sai, T. Kondo, M. Inoue,

25 Chem. Commun. 2009, 4112-4114. (c) H. Miura, K. Wada, S Hosokawa, M. Inoue, Chem. Eur. J. 2010, 16, 4186-4189. (d) H. Miura, K. Wada, S. Hosokawa, M. Inoue, ChemCatChem 2010, 2, 1223-1225. (e) M. Nishiumi, H. Miura, K. Wada, S. Hosokawa, M. Inoue, Adv. Synth. Catal. 2010, 352, 3045-3052. (f) H. Miura, S.

30 Shimura, S. Hosokawa, S. Yamazoe, K. Wada, M. Inoue, Adv. Synth. Catal. 2011, accepted.

4 For example, see (a) R. T. Brown, J. A. Joule, P. G. Sammes, In Comprehensive Organic Chemistry; S. D. Barton, W. D. Ollis, Pergamon Press: Oxford, 1979, 4, 441. (b) G. P. Ellis, In The

35 Chemistry of Heterocyclic Compounds; Wiley: Chichester, 199247.

5 (a) L. S. Hegedus, Angew. Chem., Int. Ed. 1988, 27, 1113-1226. (b) U. Pindur, R. Adam, J. Heterocycl. Chem. 1988, 25, 1-8. (c) T. L. Gilchrist, J. Chem. Soc. Perkin Trans. 1 1999, 2849-2866. (d) Gribble, G. W. J. Chem. Soc., Perkin Trans. 1 2000, 1045-1075. (e)

$4 \quad$ G. R. Humphrey, J. T. Kuethe, Chem. Rev. 2006, 106, 2875-2911. (f) J. Barluenga, F. Rodríguez, F. T. Fañanás, Chem. Asian J. 2009, 4, 1036-1048.

6 (a) J. Bakke, H. Heikman, E. B. Hellgren Acta Chem. Scand. BOrg. Chem. 1974, 28, 393-398. (b) W. Hammerschmidt, A. Baiker,

45 A. Wokaun, W. Fluhr, Appl. Catal. 1986, 20, 305-312. (c) Japanese Kokai, 88-23861, Chem. Abstr. 1988, 109, 170230. (d) Japanese Kokai, 87-114958, Chem. Abstr. 1987, 107, 154240. (e) Japanese Kokai, 81-5459, Chem. Abstr. 1981, 95, 97580.

7 Japanese Kokai, 77-142063, Chem. Abstr. 1978, 88, 120988.

508 (a) Y. Tsuji, K.-T. Huh, Y. Yokoyama, Y. Watanabe, J. Chem. Soc. Chem. Commun. 1986, 1575-1576. (b) Y. Tsuji, S. Kotachi, K.-T. Huh, Y. Watanabe, J. Org. Chem. 1990, 55, 580-584.

9 T. Izumi, T. Yokota, J. Heterocycl. Chem. 1992, 29, 1085-1090.

10 K. Fujita, K. Yamamoto, R. Yamaguchi, Org. Lett. 2002, 4, 26912694.

11 For recent examples, see (a) T. Hara, K. Mori, T. Mizugaki, K. Ebitani, K. Kaneda, Tetrahedron Lett. 2003, 44, 6207-6210. (b) K. Shimizu, K. Ohshima, A. Satsuma, Chem. Eur. J. 2009, 15, 99779980. (c) J. W. Kim, J. He, K. Yamaguchi, N. Mizuno, Chem. Lett. 2009, 38, 920-921. (d) T. Oishi, K. Yamaguchi, N. Mizuno, Angew. Chem. Int. Ed. 2009, 48, 6286-6288. (e) J. W. Kim, K. Yamaguchi, N. Mizuno, J. Catal. 2009, 263, 205-208.

12 For representative examples of organic reactions promoted by heterogeneous $\mathrm{CeO}_{2}$-based catalysts, see : (a) F. Vocanson, Y. P. Guo,

65 J. L. Namy, H. B. Kagan, Synth. Commun. 1998, 28, 2577-2582. (b) H. Ji, T. Mizugaki, K. Ebitani, K. Kaneda, Tetrahedron Lett. 2002, 43, 7179-7183. (c) K. Ebitani, H. Ji, T. Mizugaki, K. Kaneda, J. Mol. Catal. A, 2004, 212, 161-170. (d) S. Carrettin, J. Guzman, A. Corma,
Angew. Chem. Int. Ed. 2005, 44, 2242-2245. (e) A. Corma, C.

70 Gonzalez-Arellano, M. Iglesias, F. Sanchez, Angew. Chem. Int. Ed. 2007, 46, 7820-7822. (f) Y. Hayashi, S. Hosokawa, S. Imamura, M. Inoue, J. Ceram. Soc. Jpn. 2007, 115, 592-596.

13 J. W. Cook, Jr., D. E. Sayers, J. Appl. Phys. 1981, 52, 5024-5031.

14 (a) M. D. Smith, A. F. Stepan, C. Ramarao, P. E. Brennan, S. V. Ley,

75 Chem. Commun. 2003, 2652-2653. (b) S. P. Andrews, A. F. Stepan, H. Tanaka, S. V. Ley, M. D. Smith, Adv. Synth. Catal. 2005, 347, 647-654. (c) U. Kazmaier, S. Hähn, T. D. Weiss, R. Kautenburger, W. F. Maier, Synlett, 2007, 2579-2583.

15 (a) N. T. S. Phan, M. Van Der Sluys, C. W. Jones, Adv. Synth. Catal. 80 2006, 348, 609-679. (b) M. Weck, C. W. Jones, Inorg. Chem. 2007, 46, 1865-1875, and references therein.

16 S. Hosokawa, H. Kanai, K. Utani, Y. Taniguchi, Y. Saito, S. Imamura, Appl. Catal. B Environ. 2003, 45, 181-187.

17 S. Hosokawa, S. Nogawa, M. Taniguchi, K. Utani, H. Kanai, S. Imamura, Appl. Catal. A: General, 2005, 288, 67-73.

18 K. Getty, M. U. Delgado-Jaime, P. Kennepohl, Inorg. Chim. Acta 2008, 361, 1059-1065.

19 C. E. Boman, Acta Chem. Scand. 1970, 24, 116-122.

20 (a) S. Hosokawa, Y. Fujinami, H. Kanai, J. Mol. Catal. A Chem. 2005, $90 \quad 240,49-54$. (b) T. Yasueda, S. Kitamura, N. Ikenaga, T. Miyake, T. Suzuki, J. Mol. Catal. A: Chem. 2010, 323, 7-15.

21 E. Guglielminotti, F. Boccuzzi, M. Manzoli, F. Pinna, M. Scarpa, J. Catal. 2000, 192, 149-157. 


\section{Supplementary Information}

\section{Ceria-Supported Ruthenium Catalysts for the Synthesis of Indole via Dehydrogenative}

\section{$N$-Heterocyclization}

Shun Shimura, ${ }^{[\mathrm{a}]}$ Hiroki Miura, ${ }^{[\mathrm{a}]}$ Kenji Wada, ${ }^{[\mathrm{a}]} *$ Saburo Hosokawa, ${ }^{[\mathrm{a}]}$ Seiji Yamazoe, ${ }^{[\mathrm{b}]}$ and Masashi Inoue ${ }^{[\mathrm{a}] *}$

[a] Mr. Shun Shimura, Mr. Hiroki Miura, Dr. Kenji Wada, ${ }^{*}$ Dr. Saburo Hosokawa, ${ }^{[a]}$ and Prof. Dr.

Masashi Inoue*

Department of Energy and Hydrocarbon Chemistry, Graduate School of Engineering,

Kyoto University, Katsura, Nishikyo-ku, Kyoto 615-8510 (Japan)

Fax: $(+81) 75-383-2479$

E-mail: wadaken@scl.kyoto-u.ac.jp

[b] Dr. Seiji Yamazoe

Department of Materials Chemistry, Graduate School of Science and Technology

Ryukoku University, Seta, Otsu 520-2194 (Japan)

Fax: (+81)77-543-7483

E-mail: yamazoe@rins.ryukoku.ac.jp 


\section{Nitrogen gas adsorption analysis of the catalyst}

BET surface areas of representative supported catalysts used in the present study are summarized in

Table $\mathrm{S} 1$. The $\mathrm{Ru} / \mathrm{CeO}_{2}(\mathrm{KOH})-400$ catalyst showed typical type IV nitrogen

adsorption/desorption isotherms, which indicate that their pore sizes were within the mesopore

region. The catalysts supported on $\mathrm{CeO}_{2}-\mathrm{ZrO}_{2}$ mixed oxides had slightly smaller BET surface

areas than those supported on pure ceria and zirconia.

Table S1. BET surface areas of the catalysts

\begin{tabular}{ccc|ccc}
\hline Entry & Catalyst & $\begin{array}{c}\text { BET surface } \\
\text { area }\left(\mathrm{m}^{2} / \mathrm{g}\right)\end{array}$ & Entry & Catalyst & $\begin{array}{c}\text { BET surface } \\
\text { area }\left(\mathrm{m}^{2} / \mathrm{g}\right)\end{array}$ \\
\hline 1 & $\mathrm{Ru} / \mathrm{CeO}_{2}(\mathrm{KOH})-400$ & 102 & 6 & $\mathrm{Ru} / \mathrm{SiO}_{2}-400$ & 269 \\
2 & $\mathrm{Ru} / \mathrm{CeO}_{2}(\mathrm{KOH})-200$ & 112 & 7 & $\mathrm{Ru} / \mathrm{Al}_{2} \mathrm{O}_{3}-400$ & 142 \\
3 & $\mathrm{Ru} / \mathrm{ZrO}_{2}-400$ & 95 & 8 & $\mathrm{Ru} / \mathrm{CeO}_{2}-\mathrm{ZrO}_{2}(80 / 20)$ & 66 \\
4 & $\mathrm{Ru} / \mathrm{MgO}^{-400}$ & 148 & 9 & $\mathrm{Ru} / \mathrm{CeO}_{2}-\mathrm{ZrO}_{2}(50 / 50)$ & 55 \\
5 & $\mathrm{Ru} / \mathrm{TiO}_{2}-400$ & 49 & 10 & $\mathrm{Ru} / \mathrm{CeO}_{2}-\mathrm{ZrO}_{2}(20 / 80)$ & 82 \\
\hline
\end{tabular}

\section{XRD patterns of the supported-Ru catalysts calcined at $400{ }^{\circ} \mathrm{C}$}

XRD patterns of Ru catalysts supported on various oxides are shown in Figure $\mathrm{S} 1$. The calcination temperature was $400{ }^{\circ} \mathrm{C}$. Peaks due to crystalline $\mathrm{RuO}_{2}$ were observed for $\mathrm{Ru}$ catalysts supported on $\mathrm{SiO}_{2}$ and $\mathrm{Al}_{2} \mathrm{O}_{3}$. On the other hand, such peaks were not observed for catalysts supported on $\mathrm{CeO}_{2}$, $\mathrm{ZrO}_{2}, \mathrm{TiO}_{2}$, and $\mathrm{MgO}$, which implied the formation of dispersed $\mathrm{Ru}$ species on the surface. The XRD patterns of $\mathrm{CeO}_{2}-\mathrm{ZrO}_{2}$ mixed oxides are shown in Figure S2. Diffraction peaks due to the mixed oxides shifted toward lower angles with an increase in the $\mathrm{Ce} / \mathrm{Zr}$ ratio, indicating the formation of solid solutions of ceria and zirconia. 


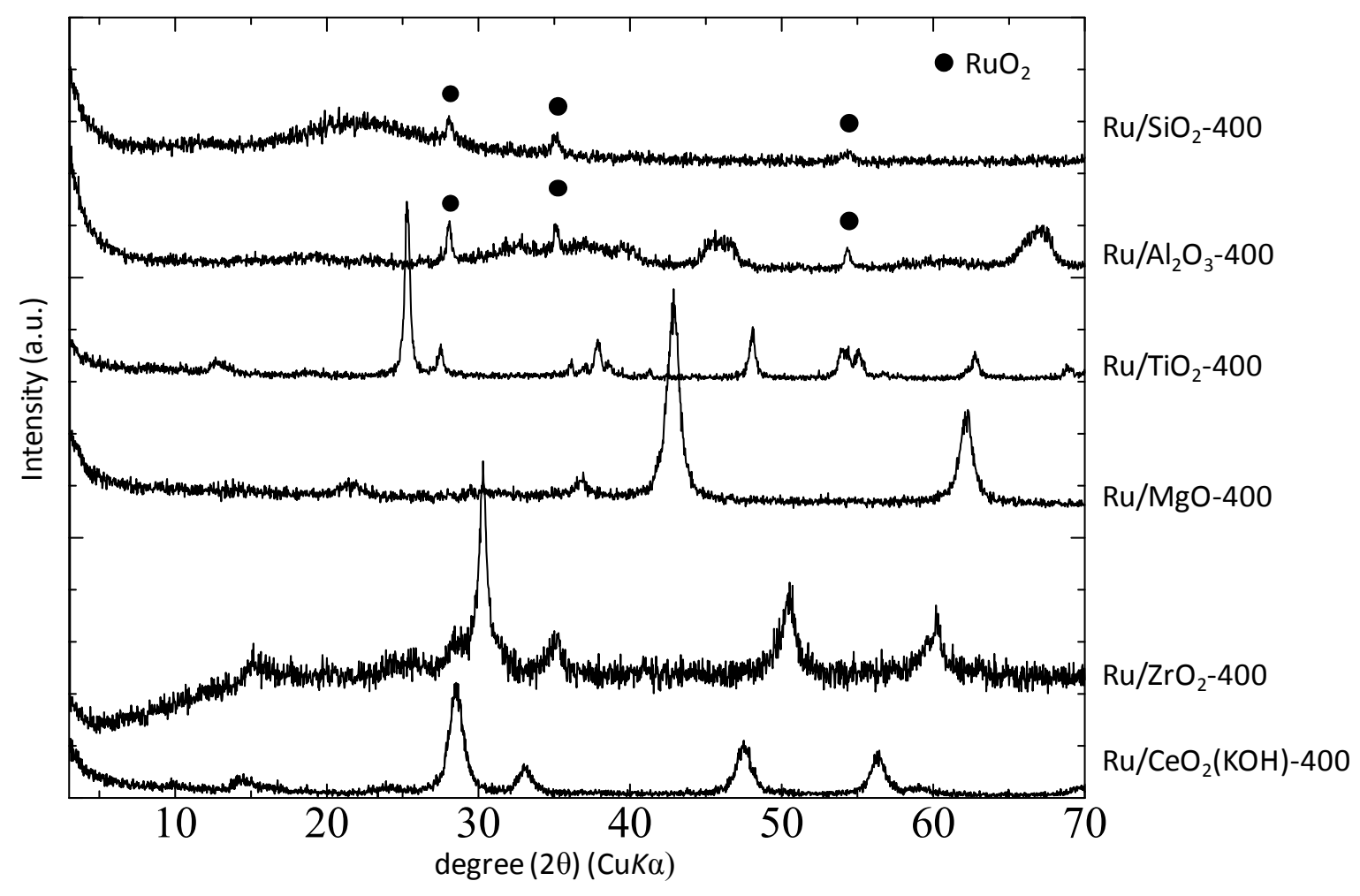

Figure S1. XRD patterns of the supported-Ru catalysts calcined at $400^{\circ} \mathrm{C}$.

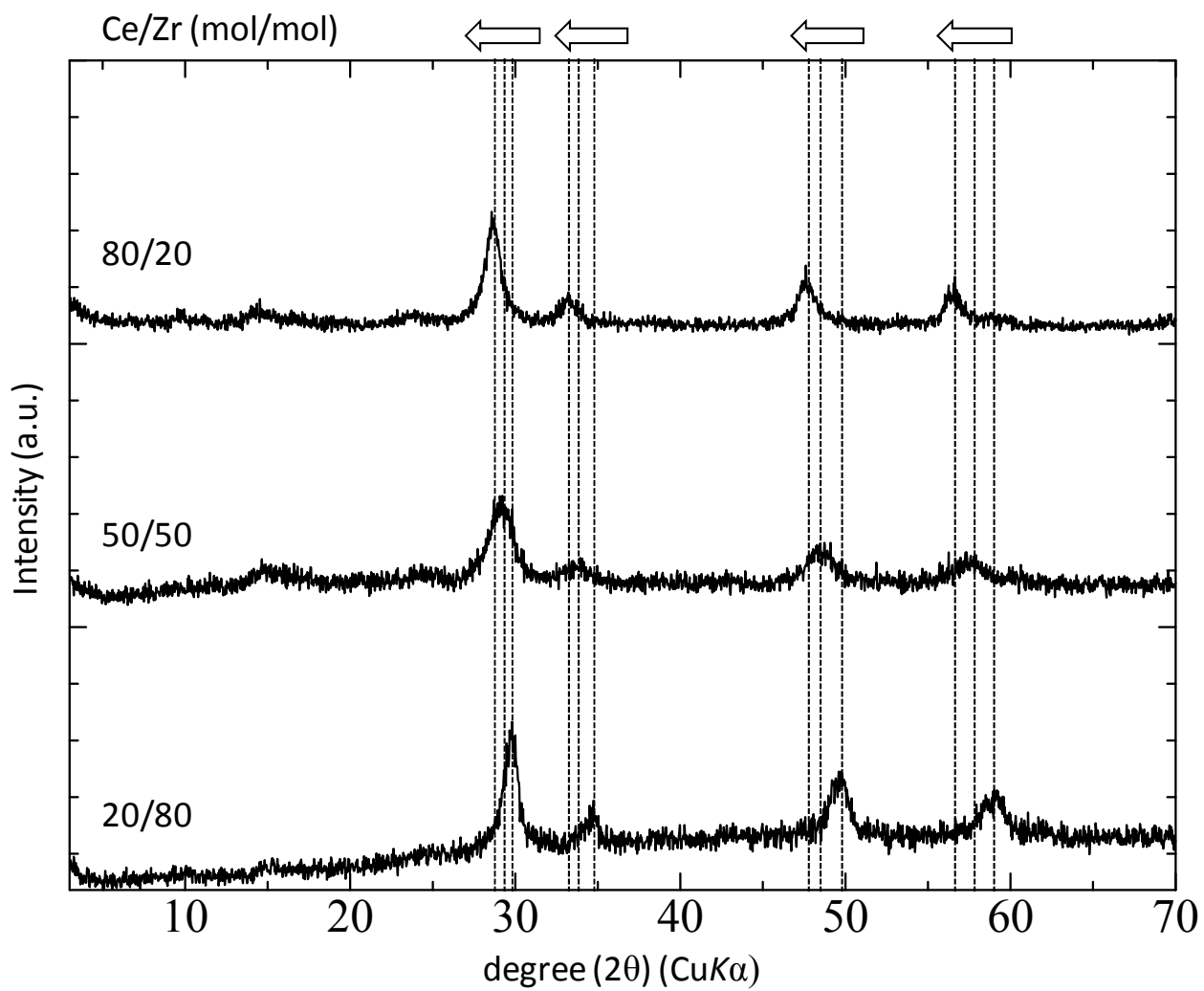

Figure S2. XRD patterns of ceria-zirconia mixed oxides 


\section{TG-DTA profiles of as-impregnated $\mathrm{Ru} / \mathrm{CeO}_{2}$}

Figure S3 shows TG-DTA profiles of as-impregnated $\mathrm{Ru} / \mathrm{CeO}_{2}(\mathrm{KOH})$ in air. There was an exothermic weight decrease at around $200{ }^{\circ} \mathrm{C}$, and the extent of this decrease is almost consistent with the weight of acetylacetonato ligands in the catalyst (5.6\%).

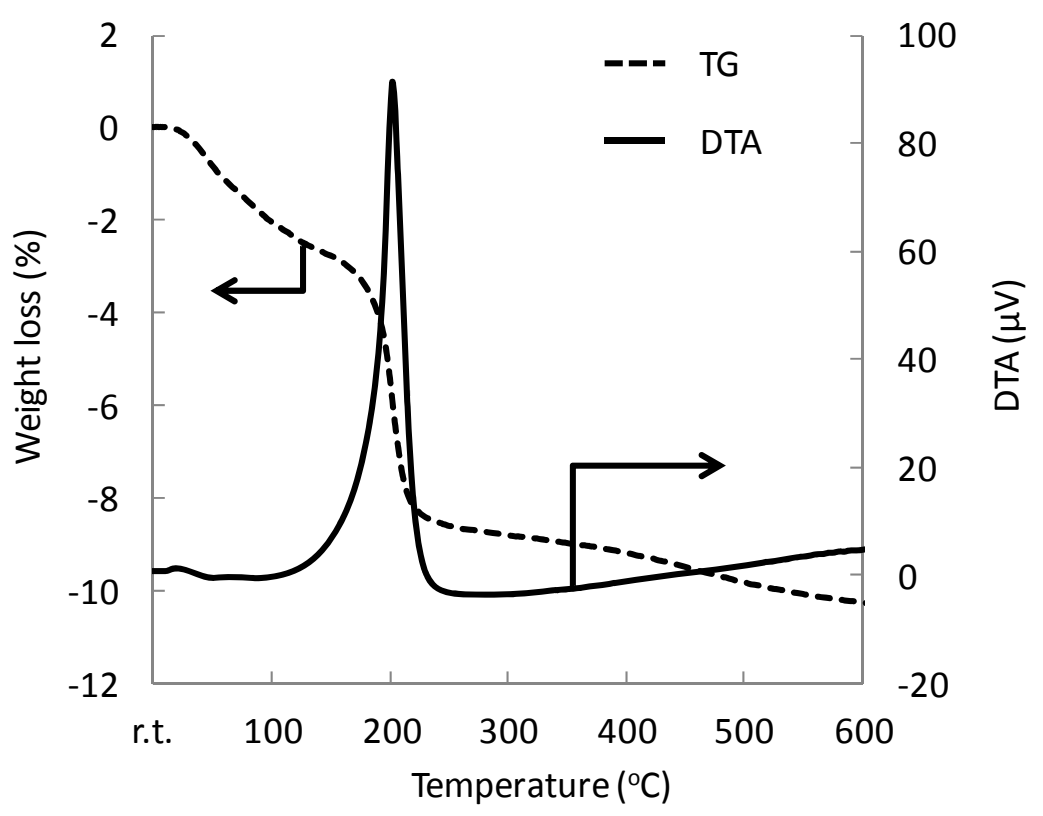

Figure S3. TG-DTA profile of $\mathrm{Ru} / \mathrm{CeO}_{2}(\mathrm{KOH})$-as-imp. 